\title{
INTELIGENCIJA I OSOBINE LIČNOSTI KAO PREDIKTORI USPEŠNOSTI MUZIČKI DAROVITIH SREDNJOŠKOLACA
}

\author{
Jasmina Pekić ${ }^{1}$ \\ Odsek za psihologiju, Filozofski fakultet, Novi Sad
}

\begin{abstract}
Shodno saznanjima o najoptimalnijem načinu predikcije uspešnosti u populaciji darovitih, ovaj rad pretenduje da ispita eksplikativnu moć prediktorskih modela koji udružuju opštu inteligenciju sa raznovrsnim ličnosnim varijablama, pri čemu se u svojstvu kriterijumskih varijabli nalaze dve latentne dimenzije muzičke uspešnosti. Osim pomenute opšte inteligencije, u predviđanje dimenzija muzičke uspešnosti uključene su sledeće varijable iz domena ličnosti: specifične crte postulirane u okviru Petofaktorskog modela ličnosti, dispozicija za originalnost $i$ dimenzija rigidnosti. Istraživanje je obavljeno na uzorku od 211 učenika srednjih muzičkih škola sa teritorije Beograda i Novog Sada, a prikupljeni podaci su obradeni postupkom multiple regresione analize. Dobijeni rezultati, sa jedne strane nude potvrdu nalaza o važnosti inteligencije $i$ motivacionih svojstava ličnosti u kontekstu muzičke uspešnosti, a sa druge strane dopunjuju postojeći korpus saznanja, ukazujući na važnost nekih novih personalnih karakteristika u ovladavanju domenom muzike.
\end{abstract}

Ključne reči: predikcija muzičke uspešnosti, inteligencija, osobine ličnosti

\section{Uvod}

U literaturi koja se bavi predikcijom uspešnosti darovitih pojedinaca, nailazi se na konstatacije o nedovoljnoj proniknutosti u ovu problematiku, pri čemu se eksplicitno navodi da razlozi visokog postignuća jednih, odnosno, podbacivanja drugih darovitih pojedinaca, još uvek, dobrim delom, ostaju u sferi misterije (McCoach, 2002). Shodno tome, susrećemo se i sa prilično ujednačenim kvantitativnim procenama veličine nepoznatog dela ovog fenomena, pri čemu se navodi da najoptimalniji prediktivni modeli objašnjavaju oko $50 \%$ varijanse uspešnosti u kontekstu darovitosti (Brody, 1992, prema McCoach, 2002;

\footnotetext{
${ }^{1}$ E-mail: jasminadream@yahoo.com
} 
Trost, 2000). Ako tome pridodamo i podatak da ovaj procenat teži opadanju u longitudinalnim istraživanjima, moglo bi se sa punim pravom reći da smo upoznati sa „manje od pola onoga što determiniše uspešnost“, a tiče se populacije darovitih (Trost, 2000, str. 323). No, napori koji se ulažu u cilju demistifikacije ovog fenomena nisu nimalo zanemarljivi. Naime, uspešnost darovitih pojedinaca prerasta u razrađenu oblast empirijske eksploracije koja pretenduje da „nedovoljnu proniknutost“ prenebregne, kako raznovrsnošću razmatranih prediktorskih varijabli, tako i svojevrsnom ekstenzijom kriterijumske varijable sa nižih na više nivoe školovanja, odnosno na nivo profesionalnog angažovanja darovitih.

\section{Psihološki prediktori uspešnosti muzički darovitih - vrste i eksplikativni dopri- nos}

S obzirom da je već prethodno istaknuto da se najveći dometi u objašnjavanju uspešnosti darovitih pojedinaca postižu optimalnim modelima predikcije, sasvim je jasno da ne postoji jedan isključivi prediktor ove varijable. Štaviše, pokušaji što celovitijeg objašnjenja uspešnosti u populaciji darovitih, bez obzira na razmatrani nivo ove varijable, podrazumevaju kombinovanje različitih kognitivnih i nekognitivnih, odnosno individualnih i vanindividualnih faktora, što ishodi iz saznanja o multidimenzionalnoj prirodi fenomena darovitosti. Naime, shodno prethodnim teorijskim i empirijskim saznanjima o prirodi darovitosti, ovi faktori su naznačavani u aspektu sposobnosti, personalnih karakteristika i sredinskih prilika darovitih. Na ovom mestu će se predočiti rezultati istraživanja predikcije uspešnosti muzički darovitih u aspektu sposobnosti i osobina ličnosti, s obzirom da je taj segment istraživačkih nalaza od posebnog značaja za empirijski deo rada.

Sposobnosti. Premda ne postoji jedan isključivi prediktor uspešnosti darovitih pojedinaca, pojedini prediktori prednjače u pogledu veličine eksplikativnog doprinosa, u odnosu na druge razmatrane prediktore. Imajući u vidu prethodna saznanja o sposobnostima kao ključnom sastojku darovitosti, nimalo ne iznenađuje podatak da opšte intelektualne i specifične kognitivne sposobnosti predstavljaju najznačajnije prediktore uspešnosti u akademskim domenima (Benbow \& Arjmand, 1990; Birx, 1988, prema Trost, 2000; Parkerson, Lomaks, Schiller $\mathcal{E}$ Walberg, 1984), dok se uspešnost u umetničkim domenima pokazala mogućom i u odsustvu natprosečnih vrednosti globalnog kvocijenta inteligencije, zbog čega se najpouzdanije predviđa na osnovu specifičnih kognitivnih sposobnosti (Radoš, Kovačević, Bogunović, Ignjatović \& Acić, 2003; Trost, 2000). No, razmatranja relacije između konstrukta opšte inteligencije i uspešnosti u domenu muzike, kao jednom od umetničkih domena darovitosti, 
sugerišu unekoliko neusaglašene nalaze. Naime, dok pojedini empirijski nalazi nude potvrdu o postojanju pozitivne, ali vrlo niske korelacije između muzičkih sposobnosti i nivoa opšte inteligencije (Shuter-Dyson \& Gabriel, 1981, prema Winner, 2003), neki drugi ishodi razmatranja ove problematike sugerišu da muzički daroviti učenici ostvaruju visoko akademsko postignuće, pri čemu je prosečna vrednost kvocijenta inteligencije ispitivanog uzorka iznosila 130 (Csikszentmihalyi, Rathunde \& Whalen, 1993). Kad je reč o prediktivnoj moći specifičnih kognitivnih sposobnosti, u jednom domaćem istraživanju uspešnosti učenja muzike na osnovnoškolskom uzrastu, ustanovljeno je preimućstvo muzičkih sposobnosti, u odnosu na ostale varijable iz aspekta kognicije (Radoš et al., 2003). Reč je, zapravo, o posve specifičnim sposobnostima operacionalizovanim preko postignuća na Gordonovim testovima elementarnog muzičkog čuvenja, te Bentlijevim testovima muzičkih sposobnosti koji su najbolje predviđali školsko postignuće u relevantnim nastavnim predmetima (posebno solfeđu), te uspešnost u ovladavanju programskim zahtevima. Što se tiče ostalih kognitivnih sposobnosti, perceptivno-motoričke sposobnosti, operacionalizovane preko postignuća na Bender-Geštalt testu, takođe su se pokazale podesnim za svrhu predviđanja uspešnosti u početnom ovladavanju domenom muzike, naročito $u$ aspektu uspešnosti u čitanju sa lista.

Personalne karakteristike. Za razliku od sposobnosti koje se prilikom predikcije uspešnosti uvek saobražavaju konkretnom domenu, određene personalne karakteristike su se pokazale univerzalnim prediktorima uspešnosti. Kada bi se činioci iz ove kategorije trebali rangirati spram veličine doprinosa u objašnjenju varijabiliteta kriterijumske varijable, najvišu poziciju bi zauzela motivaciona svojstva ličnosti. Naime, u određenim istraživanjima ove problematike, ustanovljeno je da motivacioni činioci, odmah posle sposobnosti, ostvaruju najrelevantniji doprinos u predviđanju uspešnosti pojedinaca darovitih u različitim domenima, te da se vrednosti koeficijenata korelacije ovog tipa prediktora i kriterijumske varijable, kreću u rasponu od 0.20-0.35 (Hansford \& Hattie, 1982, prema Trost, 2000; McCoach, 2002; Uguroglu \& Walberg, 1979). Pri tome se, pre svega, misli na onaj vid motivacije koji pojedini autori nazivaju posvećenost zadatku ili orijentacija na zadatak, a koji se prevashodno manifestuje kroz spremnost na ulaganje velikog truda i napora u ovladavanju određenim domenom, te perzistenciju u obavljanju ovih aktivnosti i pored nailaženja na brojne prepreke (Ames, 1992). U vezi sa motivacionim svojstvima, kao činiocima koji dobro predviđaju uspešnost u određenom domenu, je i konstrukt self-koncepta, tačnije „akademskog self-koncepta“ (Lyon, 1993) ili „selfkoncepta u odnosu na sposobnosti“ (Bloom, 1976, prema Trost, 2000). Selfkonceptu se pripisuje neka vrsta posredujućeg delovanja između sposobnosti i motivacije i u pojedinim istraživanjima je ustanovljeno postojanje visoke po- 
vezanosti ovog konstrukta sa uspešnošću u različitim domenima (Marsh et al., 1995, prema McCoach, 2002), koja sugeriše da self-koncept objašnjava čak trećinu varijanse kriterijumske varijable (Lyon, 1993).

Osim dispozicija motivacionog karaktera, ustanovljena je i povezanost nekih drugih personalnih karakteristika sa uspešnošću u širokom rasponu domena darovitosti. Reč je, naime, o svojstvima poput nezavisnosti, kako u intelektualnom, tako i u emocionalnom smislu, preferencije individualnosti u radu, nekonvencionalnosti, radikalizma u mišljenju, te različitih domenospecifičnih interesovanja (Li \& Adamson, 1992, prema Udvari \& Schneider, 2000; McCoach, 2002). Osim ovih „univerzalnih“ prediktora uspešnosti darovitih, pojedina istraživanja istakla su važnost još nekih činilaca ovog tipa, a za svrhu predviđanja uspešnosti u konkretnim domenima. U pomenutom domaćem istraživanju uspešnosti u učenju muzike na osnovnoškolskom uzrastu ustanovljen je značaj emocionalne stabilnosti, relaksiranosti, nezavisnosti i samopouzdanja (Radoš et al., 2003), dok su neka strana istraživanja uspešnosti u muzičkom izvođenju istakla posebnu prediktivnu relevantnost doživljaja samoefikasnosti (McCormick, 2003). No, iako važna, ova grupa prediktora ostvaruje skroman doprinos u objašnjenju varijanse uspešnosti, koji se očituje u koeficijentu korelacije sa kriterijumom sa prosečnom vrednošću od 0.12 (Fraser, Walberg, Welch \& Hattie, 1987).

Ovaj rad pretenduje da proveri eksplikativni doprinos „kombinovanih“ prediktorskih modela uspešnosti muzički darovitih srednjoškolaca, koji udružuju opštu inteligenciju sa nizom varijabli iz domena ličnosti. Ovakva selekcija prediktora proizilazi iz shvatanja optimalnih modela predikcije uspešnosti darovitih kao kombinacije kognitivnih i nekognitivnih faktora, pri čemu je prisutno očekivanje da će istraživanje ponuditi jasniji odgovor o ulozi opšte inteligencije u kontekstu muzičke darovitosti, te ukazati na ličnosne varijable koje dobro predviđaju muzičku uspešnost, a u prethodnim istraživanjima ove problematike nisu dovođene u relaciju sa potonjim konstruktom. $\mathrm{S}$ obzirom da je varijabla muzička uspešnost predstavljena preko dve svoje latentne dimenzije ustanovljene $u$ ranijem istraživanju strukture ovog konstrukta (Štula, 2007), rad, takođe, pretenduje da ispita sličnosti i razlike u predikciji dva kvalitativno različita, ali uzajamno povezana aspekta muzičke uspešnosti. Naime, ranijim ispitivanjem latentnog prostora varijable muzička uspešnost, koja je za indikatore imala školske ocene iz relevantnih nastavnih predmeta, učešća i nagrade na takmičenjima, te nastavničke procene različitih aspekata muzičkog izvođenja, ekstrahovana su dva faktora. Prvi ekstrahovani faktor najzasićeniji je sledećim indikatorima muzičke uspešnosti: doslednost u izvođenju, tačnost teksta, održavanje ritma, spretnost u izvođenju, te ujednačenost teh- 
ničkih detalja u okviru celine, pri čemu bi se moglo reći da pomenuti aspekti muzičkog izvođenja predstavljaju predmet evaluacije i u školskom radu, i u situaciji takmičenja. Sasvim je očigledno da se prvi izolovani faktor, prevashodno, tiče onoga što Vinerova naziva „tehničkim“ ili „strukturalnim“ aspektima muzičkog talenta (Winner, 1996), zbog čega je imenovan kao uspešnost u tehničkim aspektima muzičkog izvođenja. Drugi faktor, prvenstveno, okuplja indikatore poput: karaktera i stila izvođenja, individualnosti u interpretaciji, te donošenja celine, koji se, takođe, favorizuju i u školskim okvirima i na nivou takmičenja. Na osnovu sadržaja najreprezentativnijih manifestnih varijabli, drugom faktoru je dodeljen naziv uspešnost $u$ izgrađivanju jedinstvenog stila muzičkog izvođenja. S obzirom na visinu koeficijenta korelacije među faktorima $(r=.358)$, moglo bi se reći da raznovrsno operacionalizovana muzička uspešnost, razmatrana na uzorku darovitih srednjoškolaca, predstavlja kompozitnu varijablu koja objedinjuje dva kvalitativno različita, ali uzajamno povezana aspekta.

\section{Metod}

\section{Varijable i instrumenti}

Imajući u vidu gore pomenutu optimizaciju prediktorskog modela, u svojstvu nezavisnih/prediktorskih varijabli figurišu:

- intelektualne sposobnosti, koje su definisane kao sposobnosti logičkog rezonovanja na različitoj vrsti materijala, a koje se zasnivaju na brzini i efikasnosti elementarnih kognitivnih procesa (Wolf, Momirović i Džamonja, 1992). Intelektualne sposobnosti su operacionalizovane preko postignuća na Kibernetičkoj bateriji testova inteligencije KOG 3, a zbog usmerenosti na sporni doprinos opšte inteligencije u objašnjenju varijanse muzičke uspešnosti, u obzir je uzet ukupan skor na tri subtesta u okviru pomenute baterije (Test upoređivanja slika IT-1, Test sinonima-antonima AL-4 i Test spacijalizacije S-1);

- specifične crte ličnosti postulirane u okviru Petofaktorskog modela ličnosti Koste i MekKrea, koji pretpostavlja da se prostor bazične strukture ličnosti može opisati duž pet širokih domena, u okviru kojih je naznačeno po šest užih aspekata ili crta ličnosti. Reč je o sledećim domenima, odnosno facetama: neuroticizam (anksioznost, hostilnost, depresivnost, socijalna nelagodnost, impulsivnost i vulnerabilnost), ekstraverzija (toplina, druželjubivost, asertivnost, aktivitet, potraga za uzbuđenjem i pozitivne emocije), otvorenost (fantazija, estetika, osećanja, akcija, ideje i vrednosti), sa- 
radljivost (poverenje, iskrenost, altruizam, popustljivost, skromnost i blaga narav) i savesnost (kompetencija, red, dužnost, postignuće, samodisciplina i promišljenost) (Costa \& McCrae, 1985, prema Knežević, Džamonja-Ignjatović i Đurić-Jočić, 2004). U ispitivanju specifičnih crta ličnosti iz Petofaktorskog modela upotrebljen je inventar ličnosti NEO-PI-R, koji predstavlja pokušaj operacionalizacije ovog modela, a koji su kod nas standardizovali Knežević i saradnici.

- dispozicija za originalnost koja se definiše kao područje uma na prelazu između svesnog i nesvesnog, gde se generišu pojmovi ili predstave koji su u osnovi originalnosti (Holland, 1968). Dispozicija za originalnost merena je Holandovom SPA skalom predsvesne aktivnosti. Skala je koncipirana kao instrument koji treba da pruži opštu meru originalnosti, pri čemu visok skor na ovoj skali podrazumeva efikasnost pojedinca u korišćenju vlastitih predsvesnih procesa (tj. saznanje „da ovi nisu atrofirali pod uticajem represivnog obrazovanja ili da nisu paralizovani ili iskrivljeni pod dejstvom nesvesnih procesa" (Holland \& Baird, 1968, prema Altaras, 2006, str. 202);

- dimenzija rigidnosti koja se određuje kao otpor ka menjanju ustaljenih programa ponašanja, nasuprot fleksibilnosti koja je shvaćena kao sposobnost da se u skladu sa aktuelnim karakteristikama situacije uključuju različiti programi ponašanja (Šakotić, Genc i Milenković, 2002). Ova dimenzija merena je 30-ajtemskom skalom rigidnosti RG-1, čiji su autori Momirović i saradnici.

U svojstvu zavisne/kriterijumske varijable pojavljuje se:

- muzička uspešnost koja je operacionalizovana preko sledećih indikatora: 1. školske ocene iz relevantnih nastavnih predmeta (instrument i solfeđo), 2. učešća i nagrade na takmičenjima (školsko, smotra, festival, republičko, savezno, međunarodno), 3. nastavničke procene kvaliteta muzičkog izvođenja (tačnost teksta, spretnost u izvođenju, održavanje ritma, kvalitet tona, doslednost u izvođenju, ujednačenost tehničkih detalja u okviru celine, karakter i stil, individualnost u interpretaciji, donošenje celine). Ovakav način operacionalizacije muzičke uspešnosti predstavlja modifikaciju rešenja koje je ustanovljeno u projektu Instituta za psihologiju u Beogradu (Radoš et al., 2003). Skor ispitanika na varijabli „učešće i nagrade na takmičenjima" utvrđen je s obzirom na nivo takmičenja, pri čemu se vodilo računa o tome da li je ispitanik pored učešća osvojio i neku od prve tri nagrade. Naime, za učešće na nekom od šest nivoa takmičenja dobijala se odgovarajuća vrednost boda, pri čemu se za svaki naredni nivo vrednost 
boda povećavala za 1 (ako je bilo reči o učešću na najnižem nivou takmičenja (školsko takmičenje) ispitanik je dobijao 1 bod, na sledećem nivou (smotra) ispitanik je dobijao 2 boda itd.). Ako je ispitanik učestvovao na više nivoa, u obzir je uziman samo najviši nivo takmičenja. Ovoj vrednosti boda dodavani su i bodovi za osvojene nagrade, pri čemu je za prvu nagradu na određenom nivou takmičenja ispitanik dobijao 0,3 boda, za drugu 0,2 boda, a za treću 0,1 bod. Kad je reč o varijabli „nastavničke procene kvaliteta izvođenja" ispitanik je dobijao bodove na svakom od devet specifikovanih kriterijuma u okviru samostalno konstruisane skale procene, pri čemu je vrednost boda odgovarala jednom od pet stepeni numeričke skale na kojoj je nastavnik instrumenta procenjivao dati aspekt učenikovog muzičkog izvođenja. Kao što je u teorijskom delu rada objašnjeno, na osnovu rezultata ranijeg istraživanja strukture muzičke uspešnosti, ova varijabla je reprezentovana posredstvom dve svoje latentne dimenzije: dimenzije uspešnosti u tehničkim aspektima muzičkog izvođenja i dimenzije uspešnosti u izgrađivanju jedinstvenog stila muzičkog izvođenja.

\section{Uzorak}

Istraživanjem je obuhvaćeno 211 učenika srednjih muzičkih škola sa teritorije Beograda i Novog Sada, koji pohađaju vokalno-instrumentalni odsek. S obzirom da istraživanje obuhvata učenike specijalizovanih srednjih škola za muzički darovite, moglo bi se reći da uzorak, iako prigodan, poseduje zadovoljavajući stupanj reprezentativnosti, otuda što prijemni ispiti za ove škole podrazumevaju primenu testova specifičnih sposobnosti, pri čemu propisani minimum bodova neophodan za upis, zapravo, znači da kandidati moraju imati razvijenije muzičke sposobnosti u odnosu na prosečnu populaciju.

\section{Rezultati}

S obzirom da je muzička uspešnost predstavljena posredstvom dve pomenute latentne dimenzije, obavljene su dve multiple regresione analize kojima je ispitivan eksplikativni doprinos kombinovanih prediktorskih modela, u odnosu na svaki ekstrahovani faktor pojedinačno. U nastojanju da se ostvari što precizniji uvid u složaj prediktorskih varijabli, bazične dimenzije ili domeni iz Petofaktorskog modela predstavljeni su užim aspektima ili facetama koje su u okviru njih naznačene. No, kako bi se izbegla glomaznost prediktorskih modela, u okviru primenjenih postupaka regresione analize korišćen je "backward“ metod koračanja, pomoću kojeg su uspostavljeni „ekonomičniji“ modeli predikcije, koji posredstvom manjeg broja varijabli jednako dobro ob- 
jašnjavaju varijansu dimenzija muzičke uspešnosti. Dakle, umesto početnog skupa koji obuhvata 33 prediktora (opšta inteligencija, 30 crta ličnosti iz Petofaktorskog modela, dispozicija za originalnost i dimenzija rigidnosti), „backward“ metodom su postupno isključivani prediktori koji nemaju značajan doprinos u predikciji kriterijuma, čime su naposletku dobijeni redukovani prediktorski modeli, koji posredstvom manjeg broja varijabli jednako dobro objašnjavaju varijansu obe ekstrahovane dimenzije muzičke uspešnosti.

\section{Predikcija uspešnosti u tehničkim aspektima muzičkog izvođenja}

Rezultati prve multiple regresione analize koja za kriterijumsku varijablu ima uspešnost $u$ tehničkim aspektima muzičke izvedbe, prikazani su u donjim tabelama. Reč je, zapravo, o rezultatima koji proizilaze iz poslednje, 25. iteracije obavljene u okviru „backward“ metoda regresione analize. Kao što nam relevantne vrednosti iz tabele 1 sugerišu, crte ličnosti udružene sa inteligencijom, objašnjavaju oko $20 \%$ varijanse u tehničkim aspektima muzičke izvedbe.

Tabela 1. Koeficijent multiple korelacije

\begin{tabular}{ccccc}
\hline $\mathbf{R}$ & $\mathbf{R}^{\mathbf{2}}$ & Standardna greška & $\mathbf{F}$ & $\mathbf{p}$ \\
\hline .452 & .205 & .9008404 & 5.692 & $.000^{* *}$ \\
\hline
\end{tabular}

Tabela 2. Standardizovani regresioni koeficijenti

\begin{tabular}{lccc}
\hline \multicolumn{1}{c}{ Prediktori } & $\boldsymbol{\beta}$ & $\mathbf{t}$ & $\mathbf{P}$ \\
\hline opšta intelektualna sposobnost & .198 & 3.038 & $.003^{* *}$ \\
impulsivnost & -.140 & -2.016 & $.045^{*}$ \\
estetika & .193 & 2.874 & $.004^{* *}$ \\
osećanja & .164 & 2.066 & $.040^{*}$ \\
ideje & .223 & 3.188 & $.002^{* *}$ \\
vrednosti & -.173 & -2.606 & $.010^{*}$ \\
popustljivost & -.224 & -2.722 & $.007^{* *}$ \\
red & .289 & 2.579 & $.011^{*}$ \\
samodisciplina & .190 & 2.357 & $.019^{*}$ \\
\hline
\end{tabular}

${ }^{*} p<0.05$

** $p<0.01$

Veličine i predznaci parcijalnih doprinosa prediktorskih varijabli, predočeni u tabeli 2, ukazuju da se uspešnost u tehničkim aspektima muzičke izvedbe oslanja na specifičnu konstelaciju psiholoških varijabli koja bi se dala opisati u sledećim terminima: naglašenost urednosti i dobre organizovanosti, niska popustljivost, otvorenost uma, visoka opšta inteligencija, izražena naklonost za 
umetnost i lepo, samodisciplinovanost, niža spremnost za preispitivanje važećih pravila i vrednosti, visoka receptivnost za vlastita osećanja, te dobra kontrola impulsa i nagona.

\section{Diskusija}

Kao i u slučaju istraživanja uspešnosti darovitih u različitim domenima, predikcija uspešnosti u ovladavanju domenom muzike, i to njegovim tehničkim aspektima, nalazi oslonac u razvijenosti opšte intelektualne sposobnosti i motivacionih svojstava ličnosti, što predstavlja dodatnu potvrdu univerzalnosti ovih varijabli. Dakle, dobijeni nalazi se priklanjaju liniji istraživanja koja sugerišu značajan upliv opšte inteligencije u uspešnost muzički darovitih pojedinaca (Csikszentmihalyi et al., 1993). Moguće objašnjenje ove povezanosti moglo bi biti sadržano u činjenici da ispitivani uzorak uključuje izvođače klasične muzike, što podrazumeva interferenciju visokog socioekonomskog statusa njihovih porodica, koji ostvaruje značajnu vezu sa intenzitetom rane stimulacije (Winner, 2003). No, vodeći računa o veličini parcijalnog doprinosa zadržanih prediktorskih varijabli, moglo bi se reći da predikcija prvog ekstrahovanog faktora muzičke uspešnosti za uporišne tačke ima četiri osobine ličnosti, koje će poslužiti kao svojevrstan okvir za tumačenje raznovrsnog složaja ličnosnih varijabli iz prediktorskog modela, a to su: faceta red (iz domena Savesnost), faceta popustljivost (iz domena Saradljivost), faceta ideje (iz domena Otvorenost) i faceta estetika (iz domena Otvorenost).

Osobina reda se preciznije određuje kao urednost i dobra organizovanost i prominentnost njenog parcijalnog doprinosa prilično je razumljiva, ako uzmemo u obzir da je prvi ekstrahovani faktor, prevashodno, reprezentovan uspešnošću u aspektima muzičke izvedbe koji podrazumevaju tehničku preciznost. No, osim toga što se vezuje uz preciznost i tačnost na planu muzičke izvedbe, osobina reda, svakako, implicira i visoku motivisanost za ovladavanje relevantnim aktivnostima, u smislu da dobra organizovanost podrazumeva i visok stepen discipline. Važnost motivacije u formi discipline eksplicitnije je sugerisana crtom samodisciplina iz domena Savesnost, koja se bliže opisuje u terminima istrajavanja u obavljanju određenog zadatka i pored delovanja distraktora. Dakle, motivacija za postizanje uspešnosti u tehničkim aspektima muzičke izvedbe može se opisati kao disciplinovanost koja ima dva značenja: značenje dobre organizovanosti i značenje istrajnosti. Imajući u vidu da izgrađivanje tehničkih veština u muzici iziskuje razrađenu vežbu (deliberate practice) koja se svakodnevno sprovodi (Bastian, 1994, prema Winner, 2003), prilično je jasno zbog čega je važno da disciplinovanost bude očitovana i u aspektu dobre organizovanosti i u aspektu istrajnosti. 
Faceta popustljivost iz domena Saradljivost ostvaruje negativnu korelaciju sa kriterijumskom varijablom što, zapravo, znači, pomanjkanje inhibicije agresivnosti. No, negativan predznak crte impulsivnost iz domena Neuroticizam upućuje na, unekoliko, kontradiktorne nalaze. Moguće objašnjenje istovremene zastupljenosti osobine koja sugeriše nisku inhibiciju agresivnosti i osobine koja ukazuje na tendenciju dobre kontrole nagona i impulsa, ogleda se $u$ pretpostavci da je reč o agresivnosti koja se ne manifestuje u svom „sirovom” obliku (kao nagon ili impuls), već da se radi o nekoj vrsti prosocijalno modulirane agresivnosti, koja bi se mogla označiti izrazom prodornost. Imajući u vidu da domen muzike podrazumeva određena „pravila igre” označena kao „implicitna znanja” koja se usvajaju paralelno sa odvijanjem formalne obuke, a koja podrazumevaju upoznavanje sa strategijama „probijanja“ u domenu muzike (Subotnik \& Jarvin, 2005), osobina prodornosti bi se mogla povezati sa efikasnošću u ovladavanju ovim pravilima. Dakle, izgleda da se paralelno sa izgrađivanjem tehničkih veština muzičke izvedbe, koje predstavljaju tzv. „eksplicitna znanja”, usvaja i niz ,implicitnih znanja” koja saučestvuju u uspostavljanju kompetencije u muzičkom izvođenju (Subotnik \& Jarvin, 2005). Ovim momentom bi, dakle, bilo moguće objasniti značaj osobine prodornost u predikciji prvog faktora muzičke uspešnosti.

Predviđanje uspešnosti u tehničkim aspektima muzičke izvedbe, moguće je i ukoliko se u obzir uzme izraženost crte ideje iz domena Otvorenost. No, za bliže razumevanje značenja ove osobine, važno je naglasiti da ona figurira $u$ konstelaciji u kojoj značajnu negativnu korelaciju sa kriterijumom ostvaruje osobina vrednosti iz istog domena. Naime, istovremena zastupljenost crte koja upućuje na intelektualnu radoznalost ili otvorenost uma i crte koja sugeriše nisku sklonost ka preispitivanju važećih vrednosti, nameće potrebu za drugačijim tumačenjem otvorenosti uma, od onog uobičajenog koje se poziva na prijemčivost za nekonvencionalne ideje (Knežević i sar., 2004). Izgleda da se u ovom slučaju radi o otvorenosti za usvajanje sadržaja domena muzike, koji su, s obzirom na njegovu visoku strukturiranost, prilično „konvencionalni” i, kao takvi, ne podrazumevaju mogućnost kritičkog preispitivanja. Moglo bi se reći da je ovakvo tumačenje osobine otvorenost uma vrlo blisko opisima personalnog svojstva koje Subotnikova i Džarvinova nazivaju „,vaspitljivošću”, naglašavajući njegovu važnost u početnoj fazi razvoja muzičkog talenta, koja protiče u znaku izgrađivanja tehničke umešnosti muzičke izvedbe (Subotnik \& Jarvin, 2005).

Naposletku, predikcija uspešnosti u tehničkim aspektima muzičke izvedbe uzima u obzir i izraženost crte estetika iz domena Otvorenost, koja se bliže određuje kao naklonost za umetnost i lepo. Diskusija ovakvog nalaza mogla bi 
obuhvatiti i podatak da se značajan parcijalni doprinos beleži i u segmentu izraženosti crte osećanja iz istog domena, koja se tiče dubljeg proživljavanja sopstvenog iskustva. Naime, oba pomenuta svojstva mogla bi se dovesti u relaciju sa shvatanjima muzike kao umetničkog domena koji podstiče introspektivnost i upućenost na intrapsihički plan (Gardner, 1973, prema Sternberg, 1999), odnosno podrazumeva važnost „dispozicije za intenzivnije emocionalne doživljaje“ (Andreasen \& Glick, 1988, prema Sternberg, 1999, str. 283). Dakle, učešće crta fantazija i osećanja u predikciji uspešnosti u tehničkim aspektima muzičke izvedbe, moglo bi se protumačiti shvatanjem muzičkog izvođenja kao umetničke kategorije.

\section{Predikcija uspešnosti u aspektu jedinstvenosti muzičke izvedbe}

Rezultati druge multiple regresione analize, koja za kriterijumsku varijablu ima uspešnost $u$ izgrađivanju jedinstvenog stila muzičke izvedbe, prikazani su u donjim tabelama. Primenjeni metod „backward“ obuhvatio je 22 iteracije, pri čemu su u daljoj analizi zadržani rezultati koji se vezuju za poslednju iteraciju, koja početni, robusni skup prediktorskih varijabli (33), redukuje na „optimalnih" 12. Kao što nam relevantne vrednosti iz tabele 3 sugerišu, crte ličnosti udružene sa opštom inteligencijom, objašnjavaju oko $28 \%$ varijanse u uspešnosti izgrađivanja jedinstvenosti muzičke izvedbe.

Tabela 3. Koeficijent multiple korelacije

\begin{tabular}{ccccc}
\hline $\mathbf{R}$ & $\mathbf{R}^{\mathbf{2}}$ & Standardna greška & $\mathbf{F}$ & $\mathbf{p}$ \\
\hline .530 & .281 & .8706368 & 6.368 & $.000^{* *}$ \\
\hline
\end{tabular}

Tabela 4. Standardizovani regresioni koeficijenti

\begin{tabular}{lccc}
\hline Prediktori & $\boldsymbol{\beta}$ & $\mathbf{t}$ & $\mathbf{p}$ \\
\hline opšta intelektualna & .185 & 2.816 & $.005^{* *}$ \\
sposobnost & & & \\
hostilnost & -.134 & -1.957 & .052 \\
socijalna nelagoda & -.210 & -2.876 & $.004^{* *}$ \\
vulnerabilnost & -.124 & -1.736 & .084 \\
estetika & .184 & 2.628 & $.009^{* *}$ \\
osećanja & .183 & 2.770 & $.006^{* *}$ \\
ideje & .247 & 3.560 & $.000^{* *}$ \\
kompetencija & .194 & 2.653 & $.009^{* *}$ \\
postignuće & .183 & 2.482 & $.014^{*}$
\end{tabular}




\begin{tabular}{lccc} 
samodisciplina & .168 & 2.269 & $.024^{*}$ \\
rigidnost & -.167 & -2.236 & $.026^{*}$ \\
originalnost & .194 & 2.523 & $.012^{*}$ \\
\hline
\end{tabular}

${ }^{*} \mathrm{p}<0.05$

${ }^{* *} p<0.01$

Tabela standardizovanih regresionih koeficijenata nudi jasan uvid u specifičan složaj zadržanih prediktorskih varijabli, odnosno u veličinu i predznak njihovog parcijalnog doprinosa. Na osnovu potonjih zapažanja mogli bismo reći da su za pomenutih $28 \%$ objašnjene varijanse kriterijumske varijable zaslužne sledeće komponente prediktivnog modela: izraženost crte ideje, niska socijalna nelagodnost, naglašen osećaj vlastite efikasnosti, dispozicija za originalnost, visok nivo razvijenosti opšte inteligencije, jaka naklonost za umetnost i lepo, visoka receptivnost za vlastita osećanja, visok nivo postignuća, samodisciplinovanost, te naglašena fleksibilnost.

\section{Diskusija}

Osim opšte inteligencije, koja se pokazuje nezaobilaznom komponentom predikcije i u situaciji kada se u svojstvu kriterijumske varijable pojavljuje uspešnost $\mathrm{u}$ aspektu jedinstvenosti muzičke izvedbe, dobijeni nalazi upućuju i na važnost nekolicine ličnosnih svojstava, koja bi se mogla podeliti u četiri skupine: crte ličnosti sa predznakom prijemčivosti za novinu (ideje iz domena Otvorenost, dimenzije originalnosti i rigidnosti), crte ličnosti koje se tiču samopouzdanja (kompetencija iz domena Savesnost i socijalna nelagoda iz domena Hostilnost), motivaciona svojstva ličnosti (postignuće i samodisciplina iz domena Savesnost), te crte ličnosti koje su skopčane sa umetničkom naravi domena muzike (estetika i osećanja iz domena Otvorenost).

Prva grupa crta ličnosti sugeriše važnost prijemčivosti za novinu, kako na planu ideja, tako i na planu ponašanja, u smislu sklonosti ka lakom prebacivanju na nove programe ponašanja. Moglo bi se reći da povezanost ove grupe osobina sa kriterijumom počiva na sasvim jasnim razlozima koji se prepoznaju u sadržaju manifestnih varijabli koje najbolje reprezentuju drugi ekstrahovani faktor. Naime, s obzirom da je drugi faktor muzičke uspešnosti najzasićeniji indikatorima koji se tiču uspešnosti u uspostavljanju jedinstvenog stila muzičkog izvođenja (Štula, 2007), postaje evidentno da je za ovaj aspekt muzičke uspešnosti neobično važna sklonost ka prihvatanju novih, nekonvencionalnih ideja, te spremnost da se u skladu sa tim uključuju raznovrsni programi ponašanja. Ovaj sindrom osobina mogao bi se dovesti u relaciju sa osobinom „vaspitljivosti“ koja na stupnju favorizovanja individualnosti muzičke izvedbe 
(stupanj „ekspertize“), dobija nešto drugačiji smisao od onog koji se vezuje za ovu osobinu na stupnju izgrađivanja „kompetencije“, a koji , upravo, aludira na otvorenost za promene, shvaćenu kao menjanje tehnički usavršenog, ali "bezličnog“ stila izvođenja, u pravcu favorizovanja njegove jedinstvenosti (Subotnik \& Jarvin, 2005).

Druga grupa relevantnih prediktorskih varijabli iz domena ličnosti, organizovana je oko teme „poverenje u vlastite sposobnosti“. Naime, značajna pozitivna korelacija crte kompetencija, bliže određene kao osećaj vlastite efikasnosti, te negativna korelacija crte socijalna nelagoda, koja ukazuje na odsustvo sklonosti ka osećanju inferiornosti, jasno ukazuje da je visoko vrednovanje vlastitih sposobnosti ovladavanja domenom muzike, neobično važno za izgrađivanje jedinstvenog stila muzičke izvedbe. Tome slično, značaj samopouzdanja za uspešnost $u$ (početnom) ovladavanju domenom muzike ustanovljena je i u domaćim istraživanjima (Radoš et al., 2003), kao što su i pojedina strana istraživanja predikcije uspešnosti u muzičkom izvođenju istakla prediktivnu relevantnost doživljaja samoefikasnosti (McCormick, 2003).

Motivaciona svojstva ličnosti, kao neizostavan segment svakog prediktorskog složaja ličnosnih varijabli, predstavljena su motivom postignuća, te samodisciplinovanošću. Imajući u vidu da se prva motivaciona crta opisuje u terminima visokog nivoa aspiracija i spremnosti na ulaganje velikog truda i napora u ostvarivanju važnog cilja, a druga u terminima istrajavanja u okončavanju određenog zadatka i pored delovanja distraktora, mogli bismo reći da je reč o motivaciji tipa orijentacija na zadatak, koja podrazumeva postojanje motivisanosti „iznutra“ (Ames, 1992; Wieczerkowsky, Cropley \& Prado, 2000; Winner, 1996). Naime, u početnoj fazi ovladavanja domenom muzike, koja je fokusirana na njegove tehničke dimenzije, neobično je važna podrška roditelja (Sosniak, 1985, prema Haroutounian, 2000; Subotnik \& Jarvin, 2005), koja se shvata i kao preduslov perzistiranja deteta u domenu muzike (Freeman, 2000), što može da znači da je u početnim fazama učenja muzike prisutno preimućstvo ekstrinzičke u odnosu na intrinzičku motivaciju. No, u adolescentnoj dobi, kada roditeljska podrška gubi na insentivnosti (Subotnik \& Jarvin, 2005), a bavljenje muzikom postaje glavna odrednica identiteta mladog izvođača (Sosniak, 1985, prema Haroutounian, 2000), moglo bi se reći da motivi bavljenja muzikom ostvaruju zadovoljenje, prevashodno, u samim aktivnostima muzičkog izvođenja, a sekundarno i u nekim spoljnim podsticajima (priznatost od strane profesora, okoline, mogućnost javnog nastupanja itd.).

Naposletku, uspešnost $u$ aspektu jedinstvenosti muzičke izvedbe delom počiva na crtama ličnosti koje bi se dale povezati sa shvatanjima muzike kao umetničkog domena koji podstiče introspektivnost i upućenost na intrapsihički 
plan (Gardner, 1973, prema Sternberg, 1999). Naime, slično predikciji uspešnosti u tehničkim aspektima muzičke izvedbe, prijemčivost za umetnost i lepo, te visoka receptivnost za vlastita osećanja, ostvaruju značajnu korelaciju i sa drugim aspektom muzičke izvedbe. Shodno tome, ova svojstva bi se mogla proglasiti zajedničkim, domenospecifičnim prediktorima uspešnosti u učenju muzike na srednjoškolskom nivou.

\section{Zaključak}

Ispitivanjem predikcije uspešnosti u kontekstu muzičke darovitosti ustanovljeni su rezultati koji se, sa jedne strane, mogu smatrati potvrdom nalaza nekih ranijih istraživanja predikcije uspešnosti darovitih, a sa druge strane dopunom postojećeg korpusa saznanja o ovoj problematici. Naime, sličnost sa ranijim nalazima uočljiva je u segmentu isticanja važnosti inteligencije i motivacionih svojstava ličnosti u predviđanju uspešnosti darovitih. Dakle, poput uspešnosti u mnogim drugim domenima manifestovanja darovitosti, uspešnost u ovladavanju domenom muzike nalazi oslonac u nivou razvijenosti opšte inteligencije i motivacije, što ulogu opšte inteligencije u kontekstu muzičke darovitosti čini manje nejasnom. Značajna povezanost opšte inteligencije sa muzičkom uspešnošću najverovatnije potiče otuda što je reč o izvođačima klasične muzike, što podrazumeva interferenciju visokog socioekonomskog statusa njihovih porodica, koji ostvaruje snažnu vezu sa intenzitetom rane stimulacije (Winner, 2003).

Kad je reč o mogućnostima dopune postojećeg korpusa naučnih saznanja, mogli bismo reći da dobijeni rezultati nude nešto potpuniju sliku o ulozi specifičnih personalnih crta u dostizanju uspešnosti na različitim nivoima. Pri tome je, naime, ustanovljeno da se uspešnost $u$ tehničkim aspektima muzičke izvedbe, prevashodno oslanja na sklonost ka urednosti i dobroj organizovanosti, dok se uspešnost $u$ izgrađivanju jedinstvenog stila muzičke izvedbe najbolje predviđa na osnovu crta sa predznakom interesa za novinu. No, kako se izgrađivanje jedinstvenosti muzičke izvedbe nadovezuje na ovladanost tehničkim veštinama, ustanovljeni su i izvesni zajednički ličnosni prediktori uspešnosti u oba naznačena aspekta. Reč je, naime, o svojstvima vezanim za umetničku narav domena muzike, koja se tiču naklonosti za umetnost i lepo, te naglašene receptivnosti za vlastita osećanja. Ova svojstva bi se, stoga, mogla proglasiti domenospecifičnim prediktorima uspešnosti u kontekstu muzičke darovitosti. 


\section{Reference}

Altaras, A. (2006). Darovitost i podbacivanje. Beograd: Mali Nemo.

Ames, C. (1992). Classroom goals, structures and student motivation. Journal of Educational Psychology, 84, 261-271.

Benbow, C. P. \& Arjmand, O. (1990). Predictors of high academic achievement in mathematics and science by mathematically talented students: a longitudinal study. Journal of Educational Psychology, 82, 430-431.

Csikszentmihalyi, M., Rathunde, K. \& Whalen, S. (1993). Talented tenegers: The roots of success and failure. New York: Cambridge University Press.

Fraser, B. J., Walberg, H. J. Welch, W. W. \& Hattie, J. A. (1987). Syntheses of educational productivity research. International Journal of Educational Research, 11, 145-252.

Freeman, J. (2000). Children's talent in fine art and music - England. Roeper Review, 22(2), 98-107.

Haroutounian, J. (2000). The delights and dilemmas of the musically talented teenager. Journal of Secondary Gifted Education, 12(1), 3-15.

Holland, J. L. (1968). Preconscious Activity Scale. Retrieved June 12, 2005 from: http://www.creativelearning.com/Asess/test54

Knežević, G., Džamonja-Ignjatović, T. i Đurić-Jočić, D. (2004). Petofaktorski model ličnosti. Beograd: Društvo psihologa Srbije.

Lyon, M. A. (1993). Academic self-concept and its relationship to achievement in a sample of junior high school students. Educational and Psychological Measurement, 53, 201-210.

McCoach, D. B. (2002). A validation study of the school attitude assessment survey.

Measurement and evaluation in counseling and development, 35(2), 66-99.

McCormick, J. (2003). The role of self-efficacy in a musical performance examination: An exploratory structural equation analysis. Psychology of Music, 31(1), 37-51.

Parkerson, J. A., Lomaks, R. G., Schiller, D. P. \& Walberg, H. J. (1984). Exploring causal models of educational achievement. Journal of Educational Psychology, 76, 638-646.

Radoš, K., Kovačević, P., Bogunović, B., Ignjatović, T. \& Acić, G. (2003). Psychological foundations of success in learning music at elementary 
school age: In proceedings of the 5th Triennial Conference of the European society for the cognitive science of music (ESCOM) CD (str. 416-419). Hanover University of Music and Drama, BRD.

Sternberg, R. J. (1999). The influence of personality on artistic and scientific creativity. U R. J. Sternberg (Ed.). Handbook of creativity (p.p. 273-297). New York: Cambridge University Press.

Subotnik, R. \& Jarvin, L. (2005). Beyond expertise: Conceptions of giftedness as great performance. U R. J. Sternberg \& J. E. Davidson (Eds.), Conceptions of giftedness (pp. 343-358). New York: Cambridge University Press

Šakotić, J., Genc, L. i Milenković, S. (2002). Metrijske karakteristike i faktorska struktura skale rigidnosti RG-1. U B. Čukić i M. Franceško (Ur.), Ličnost u višekulturnom društvu, 4, (str. 156-165). Novi Sad: Filozofski fakultet, Odsek za psihologiju.

Štula, J. (2007). Struktura uspešnosti muzički darovitih srednjoškolaca. U M. Biro i S. Smederevac (Ur.) Psihologija i društvo (str. 195-207). Novi Sad: Filozofski fakultet, Odsek za psihologiju.

Trost, G. (2000). Prediction of excellence in school, higher education and work. U K. Heller, F. Mönks, R. Sternberg \& R. Subotnik (Eds.). Giftedness and talent (pp. 317-327). Oxford: Elsevier science.

Udvari, S. J. \& Schneider, B. H. (2000). Competition and the adjustment of gifted children: a matter of motivation. Roeper Review, 22(4), 212-227.

Uguroglu, M. E. \& Walberg, H. J. (1979). Motivation and achievement: a quantitative synthesis. American Educational Research Journal, 16, 375389.

Winner, E. (1996). Gifted children: Myths and realities. New York: Basic Books.

Winner, E. (2003). Creativity and talent. U M. H. Bornstein, L. Davidson, C. L. Keyes, K. A. Moore \& L. Erlbaum (Eds.), Well-being: positive development across the life course (pp. 371-379). Mahwah, N. J.: Lawrence Erlbaum Associates.

Wieczerkowsky, W., Cropley, A. \& Prado, M. (2000). Nurturing talents/gifts in mathematics. U K. Heller, F. Mönks, R. Sternberg \& R. Subotnik (Eds.), Giftedness and talent (pp. 413-425). Oxford: Elsevier science.

Wolf, B., Momirović, K. i Džamonja, Z. (1992). KOG 3. Beograd: Savez društava psihologa Srbije. 


\title{
ABSTRACT
}

\section{INTELLIGENCE AND PERSONALITY TRAITS AS THE PREDICTORS OF SUCCESS OF THE SECONDARY SCHOOL PUPILS GIFTED IN MUSIC}

\author{
Jasmina Pekić \\ Department of psychology, Philosophical faculty, Novi Sad
}

According to the knowledge about the optimal prediction of success in the gifted population, this paper attempts to explore explicative power of the prediction models which combine general intelligence and different personality traits, where, at the same time, two latent dimensions of the musical success represent criteria variables. Beside general intelligence, the prediction of two latent dimensions of musical success includes several personality variables: the facets specified in the Five-Factor model, the disposition for originality and dimension of rigidity. The research was carried on a sample of 211 secondary school pupils gifted in music, whereas the statistic procedure of multiple regression was implemented for the purpose of the data treatment. The obtained results support the relevance of both intelligence and motivation in the context of musical success, and also point out to the connection between some new personality traits and musical success.

Key words: prediction of musical success, intelligence, personality traits 